\title{
Misguided Expectations: The Ideological Framework of the Autonomous Model
}

\author{
Nancy G. Barrón - Northern Arizona University \\ Sibylle Gruber-Northern Arizona University
}

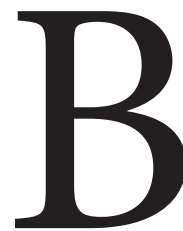

rian Street reminds us that literacy practices-the "broader cultural conception of particular ways of thinking about and doing reading and writing in cultural contexts" ("What's 'New" 79) - are always social acts and have to be defined in relation to the historical, economic, and political contexts in which they take place. As such, literacy is "always rooted in a particular world-view" and always "contested in relation to power" ("What's 'New" 77-78). Our introduction to this understanding of literacy practices as graduate students in the early 1990s gave us confidence that our literacy experiences as a Latina and as an international student from Austria would be addressed and valued. However, more than 15 years later, we are not sure how our own literacy experiences are reflected in our academic environments, and whether our literacy practices, like the practices of so many of our students and faculty colleagues, are social acts that have continued to be "contested in relation to power."

As researchers, teachers, and colleagues, we are from different countries and represent different ethnic backgrounds. One of us speaks Spanish de México; the other speaks Deutsch von Österreich. One grew up east of East Los Angeles; the other grew up in a small rural town of 900 in Austria. Nancy, with a long history of border crossing and family on both sides of the border, deportation of immediate family in the 1930s (what was at that time called Mexican-American "repatriation"), sweatshop labor in Los Angeles, and traveling blacksmiths in Arizona, attended her first high school assembly at 15 and learned that only $50 \%$ of her high school class would graduate. She finished high school, completed her undergraduate studies in California, and graduated with a $\mathrm{PhD}$ from Michigan Technological University. Sibylle, with roots in the indentured-servant class in the AustroHungarian empire, a grandfather imprisoned in a Russian internment camp during World War I, a grandmother praying that her husband would not be sent to a nearby concentration camp after being taken away for questioning during World War II, and family hoping that each of the six children would finish basic schooling at the age of 15 and then find a decent blue-collar job, was aware that continuing her schooling beyond the age of 15 was as unimaginable as a German saying Schlagobers instead of Sahne. She began her studies at the University of Vienna, finished her PhD in Illinois, and now works and lives in the United States. Our disparate long-ago histories are only connected-and interpreted very differently-through Maximilian I of Mexico, the Habsburg Austrian who served for a few unfortunate years in the 1860s as Mexico's emperor.

Despite our different backgrounds, many of our literacy experiences in US academic institutions are similar. Working class, first-generation, and outside of the English-speaking Anglo mainstream academic community, we understand that Street's discussion of literacy as ideological, where literacy 
practices can be used to dominate or marginalize others (see Besnier and Street; Street, Literacy in Theory and Practice; Social Literacies; "Literacy Events"; "What's 'New"), has remained an essential lens for understanding the multiple literacy practices we bring to academic settings. We use Street's contextual framework to highlight our own experiences as a Latina and as an Austrian faculty member in an Anglo mainstream academic community, a community that implicitly and complicitly engages in continuing and often promoting dominant hegemonic literacy practices without taking into account our transliterate, translingual, and transcultural identities, even though at the same time promoting our "Otherness" in order to highlight diversity efforts on campus. We include a narrative approach to provide examples of how our literacy practices as non-dominant faculty are steeped within an ontology that values diverse forms of meaning making. Our narratives show that the current autonomous literacy narrative promotes a hegemonic power structure that fails to value the work required to properly navigate among diverse ontologies and diverse ideological frameworks. We conclude that expanding how we define and teach literacy skills while locating ourselves simultaneously as communicators and listener-participants in academic settings disrupts current power structures and opens spaces for diverse ideologies that influence and complicate what we value and how we teach.

\section{The Mysteries of Implicit Expectations}

Similar to most people, we grew up learning about what it meant to be a part of our social, cultural, economic, gender, and ethnic groups, and we also learned what it meant to be apart from other groups. We learned early on who we can share ideas with, who agrees with us, who makes fun of us, who dismisses us, and who challenges us to think beyond the group thinking that is easy to adapt. We also learned to question the implicit assumptions and rules about the literate behaviors that were accepted and encouraged. In graduate school, we read Shirley Brice Heath's 1983 exploration of Roadville and Trackton residents whose literacy practices are largely outside of what is expected in a school setting. She concluded in a sentence about the writing done in both communities that "neither community's ways with the written word prepares it for the school's ways" (235). We also learned about the "mainstreamers" in town who were "strongly school-oriented, believing success in school, academically and socially, is a prerequisite to being successful as an adult" (236) because school, they were convinced, "helps instill values such as respectability, responsibility, and an acceptance of hard work" (237).

In 1983, we both finished high school, and we both would have fit the image of the Roadville and Trackton communities, not in terms of ethnicity or nationality, but in terms of being prepared for the "school's way." The "school's way" - which is always connected to specific power brokers and mainstream understandings of what it means to be literate, was as abstract and distant to our families as it was for the Roadville and Trackton residents. Our families, too, subscribed to the belief that "language is power," and even though they "may not articulate precisely their reasons for needing to learn to read, write, and speak in the ways the school teaches," they believed "that such learning has something to do with moving up and out" of our respective neighborhoods (Heath 265). 
Now we understand that we participated in an educational setting where literacy was seen as autonomous and where nobody would have questioned or understood what Bruce Horner pointed out in the inaugural 2013 issue of Literacy in Composition Studies. As he reminds us, "the autonomous model is powerful in claiming an autonomy for literacy that hides its ideological character, purporting to offer literacy as an ideologically neutral phenomenon-a gift to the unfortunate, who can thence be blamed for failing to make appropriate, grateful use of it to improve themselves" ("Ideologies" 2). Horner complicates the positionality of the "unfortunate" when he continues to tell us that "the set of actors and activities which that ideology does recognize as 'literate' is neither homogeneous, uniform, discrete, nor stable in character but rather a constantly shifting set of unstable, internally various, fluid, and heterogeneous practices" ("Ideologies" 2). The implicit understanding of what constitutes accepted "heterogeneous practices" in an autonomous system that is embraced by mainstream academic and professional institutions created an added hurdle for us when we entered academia. We could not claim membership in dominant mainstream discourse communities because we were not introduced to or encouraged to join these discourse communities. We learned to imitate accepted academic discourse by pretending that language was void of cultural nuances and daily realities. We removed personal value for most of our academic writing and wrote "correctly" or produced our best imitations of how we understood Anglo middle-class mainstream writing expectations.

The unacknowledged and hidden dominant ideologies within an autonomous literacy model made our participation in an academic setting even more challenging. For Sibylle, who came to the US as a graduate student, navigating US educational expectations-and navigating what were considered academic literacy practices in a culturally, politically, and socially different system that used English not in the ways studied in an Austrian education system-was not only intimidating but also alienating. Many of the pedagogical and methodological practices in rhetoric and writing classrooms, and communication practices used by faculty and fellow students, did not follow expected patterns Sibylle learned as an undergraduate at the University of Vienna, where interactions were limited to teacher-student conferences because of failing grades, and where much information was learned and reproduced through lectures and tests. Little focus was given to what James Paul Gee calls "Discourse," which highlights the "socially accepted association among ways of using language, other symbolic expressions, and artifacts, of thinking, feeling, believing, valuing and acting that can be used to identify oneself as a member of a socially meaningful group or 'social network" (Social Linguistics 131). Instead, teachers in Austria who were trained in grammar-based language learning as drill-and-kill practices did not mention that part of a successful experience in an American classroom included negotiating when and how to talk to a professor, how to ask for feedback, how to talk to classmates, and how to write the way that was acceptable for American professors. Once Sibylle started university in the US, the ELL lab set aside for "at-risk" international students focused on language not as a set of social practices but instead as a neutral set of reading and writing skills (see Street, Literacy in Theory and Practice; Social Literacies) that needed to be mastered in a vacuum, with plastic headsets and a computer as a companion.

Interacting with teachers was similarly volatile. "Work on your sentence structure!" was a comment that Sibylle received again and again in her early years at a US university. Her German- 
influenced complex sentences could rival any stream-of-consciousness novel, yet inevitably confused and annoyed instructors who evaluated her writing. None of them, however, pointed out strategies for adapting writing for the intended audience, and none of them mentioned that language practices were part of a larger social, cultural, and political system. Sibylle, as a result, was not aware in her undergraduate and early graduate career that her language background was anything but a hindrance to her education in the US. The ELL course she was required to take, and the language lab that was associated with it, emphasized the need to eliminate the "foreign" accent. An international graduate assistant training week in the late 1980s included sessions on speaking clearly and succinctly so that accents would not get in the way of US students' understanding of the subject matter. International students' previous experiences teaching, and their abilities and knowledge outside of an accented English, were not part of the discussion. Discussions also didn't include cultural differences, US politics, race politics, or social and economic issues. Those were only addressed much later, during international graduate student meetings that provided a space for exploring, explaining, and figuring out what was often implied and never said. Participation in "socially meaningful groups" took many years, and even after Sibylle's 20-plus year exposure to American educational settings, implicit rules about what is included and what is excluded from academic discourse conventions-whether communicating with colleagues, the administration, or students-can still lead to uncomfortable moments of outsider status.

For Nancy, learning was at first exciting and interesting. Nancy's third-grade teacher dusted off a sixth-grade book and gave it to her. Pre-algebra was mysterious and fun. "Discard Day" from the library resulted in large books on geography, geology, and general science. Teachers from kindergarten through third grade encouraged home literacies as part of the learning process. Spanish was accepted, and English was practiced. However, fourth grade and higher became a different challenge. With teachers who lived their "back-up plan" and wanted to be working "anywhere but here," school for Nancy became high stress and an obstacle to acquiring school literacy. Teachers were not community members, and parents were no longer encouraged to participate in their children's education. Learning was not connected to the home environment, and expectations for graduating and moving on to college were low. For this reason, it took Nancy a few years to redo high school at a local community college and then transfer to a university in Orange County during Reagan's Hands-Across-America administration, when racist comments and views were tolerated. It was during Nancy's master's program in downtown LA when her voice and discussions of personal experience were included in academic literacy practices. However, using individual voice and personal experience after hiding it for many years was not an easy task. Combining individual voice with critical reflection was even more difficult for Nancy. Learning about James Paul Gee's differentiation between acquisition and learning in "What Is Literacy" provided Nancy with her initial understanding that academic literacy included both institutional requirements and ideological and personal literacies. In other words, Gee's argument encouraged agency by enabling Nancy to decide when it was important to get through a lesson and when it was important to reflect on, interact with, and revise dominant academic practices and knowledge.

As a Latina in higher education, Nancy needed to decide what it meant to live as what Gloria 
Anzaldúa defined as living in the borderlands. As Anzaldúa points out, la mestiza, the border crosser, "constantly has to shift out of habitual formations; from convergent thinking, analytical reasoning that tends to use rationality to move toward a single goal (a Western mode), to divergent thinking, characterized by movement away from set patterns and goals and toward a more whole perspective, one that includes rather than excludes" (101). When Nancy left East Los Angeles and moved to Michigan Technological University, she often heard that her sentences were choppy and awkward, and that writing for the classroom followed a prescribed pattern. At the same time, she was encouraged to bring in her personal voice in her writing to include her experiences growing up Latina. As a result, she continuously walked "out of one culture and into another" (Anzaldúa 99), with the dissertation as a site to present critical reflections on the ideologies accepted and not accepted in education. The format of Nancy's dissertation, letters to specific audiences in English and Spanish, was familiar to Nancy and achieved what was required in an academic setting-a researched argument. Hegemonic truth no longer took precedence over the ambiguity that accompanies life in the borderlands. Before understanding the opportunities created by a broadening of academic literacy practices, Nancy's experiences were similar to those described by Anzaldúa where "the ambivalence from the clash of voices results in mental and emotional states of perplexity" (100). These "states of perplexity" are still present in Nancy's current-day interactions with students, faculty, and the administration. However, the knowledge that academic writing can include the unexpected has created new ways of moving forward and encouraging students to take agency over their writing.

\section{Making Implicit Expectations Explicit}

When we reflect on our literate lives, we see that our school literacy practices were often in conflict with established mainstream academic literacy norms, and we were often unsure why our papers received low grades. Now, we see two individuals whose literacy behaviors and membership in non-dominant and dominant literate institutions went through many stages and underwent many changes. We learned and are still learning some of the implicit academic expectations through trial and error, while maintaining a sense of academic self. We adapted to some, ignored others, and brought in our own expectations. Certainly, our careers require us to participate in dominant literacy behaviors defined and sanctioned by our institutions. We recognize that we studied in mainstream institutions. We are teachers and researchers. We evaluate student writing based on academic conventions. We accept students to our graduate program based on criteria we agreed to uphold. However, our careers, we strongly believe, also require us to expand, redefine, and make explicit to ourselves and our students with similar backgrounds to ours what is considered acceptable academic literacy behavior. We do this because of our own experiences as outside and inside the accepted norm, and we do it because we strongly support literacy scholars whose discussions on the ideological nature of literacies have guided our interactions with fellow academics and students for many years. When Bruce Horner reminded us in 2013 that all literacy is ideological, we went back to Elsa Auerbach's assertion that

all theories of literacy and all literacy pedagogies are framed in systems of values and beliefs 
which imply particular views of the social order and use literacy to position people socially. Even those views which paint literacy as a neutral, objectively definable set of skills are in fact rooted in a particular ideological perspective, and it is precisely because they obscure this orientation that they are most insidious. (72)

Our roles as change agents did not come easy. Only when we moved forward in our studies and became faculty members in a rhetoric and writing program did we learn to appreciate the nuances of our positionalities as a Latina and an Austrian. We also learned that we were in prime positions to emphasize the ontological nature of rhetoric by questioning often unquestioned academic literacy practices, and by making explicit and adapting these practices to include daily literacy events of students for whom academic discourse is secondary and outside the implicit norms used in academic environments. We learned to leave the role of the victimized whose contributions were devalued and ignored and instead moved forward to address the question asked by a mentor when we complained about how unfair academia was: "You're right. I agree. It's not fair. What are you going to do about it?" Accepting our right and responsibility to participate in unmasking what is obscured and therefore "most insidious" in dominant literacy practices has encouraged us to address what might be intentional or unintentional biases in how non-dominant literacy practices and ideologies are interpreted and evaluated.

We are reminded, when we talk to colleagues and students whose primary D/discourse (see Gee, Social Linguistics) is close to the academic institution's $\mathrm{D} /$ discourse conventions, that excluding those with different literacy practices is not always a conscious act. However, taking privilege for granted, and accepting traditional academic core values as universal and unbiased, limits an understanding of the values and practices brought to the table by those who cannot claim or are not interested in claiming unconditional membership and acceptance in a narrowly focused discourse community. We see that colleagues are evaluated according to different standards, not because their performance is different but because their gender, their nationality, or the color of their skin is different. We see that special privileges only happen to those who understand how to use their dominant literacy skills to negotiate with the administration. We also hear, when we point out inequalities, that everybody is treated-without a doubt-the same, and few recognize that privilege often connects with social, cultural, and socio-economic values. The administration insists that there is no preferential treatment, no matter who the faculty is. Faculty, at the same time, claim that all students are given the same opportunities in the classroom, take the same tests, and get the same instructions for writing papers. However, we also know that, as Lisa Delpit points out, "other people's children" are not invited to sit at the table of the dominant group if they don't adapt the dominant group's behaviors. They are not encouraged to bring to the table their own literate lives, or change the literate behaviors accepted by the dominant group. According to Delpit, this has led us to give up "the rich meaningful education of our children in favor of narrow, decontextualized, meaningless procedures that leave unopened hearts, unformed character, and unchallenged minds" (xiv).

To make sure that we can take back "the rich meaningful education" that Delpit discusses, our teaching has become an effort to expand what dominant discourse includes; discuss when, how, and why code-switching can be powerful; and encourage awareness of and participation in multiple 
literacy practices by embracing the fluidity of literacy ideologies. As Juan Guerra mentions in his piece on transcultural repositioning, it is by

invoking the power and authority inherent in our literacy practices, and especially in the strategic rhetorical ability that more and more members of our community are developing as we learn to navigate our way through the perilous social and political waters of a nation in upheaval, we may yet chart our own destiny and ensure that everyone among us is granted the right to personal agency and self-determination. ("Emerging Representations" 8)

We want this power and authority to include the literacy practices of students who have accepted that they don't fit the A-student profile, whose home literacies remind us of ourselves and of Heath's Trackton and Roadville children, and whose languages complement, enrich, and expand academic Englishes. Language ideologies and literacy ideologies, we want students to know, are part of a larger system that, once we can decode it, allows us to move in and out of that system. Whether we call it code-switching, using multiple databases, repertoire expansion, signifying, or code-meshing, we provide students with tools to participate in multiple systems without seeing any system as superior or inferior. Instead, we point to the "disjunctures, contradictions, and clashes in the ideologies of language" (Bou Ayash 7) and in the various literacy ideologies that students experience, especially the ideologies of the autonomous model. These situated and fluid literacies, then, are part of "dynamic social practices that broker, shape, react to, and redistribute linguistic power in local communities" (Alvarez 44).

\section{Moving On: Transliterate, Translingual, Transcultural}

We are both exploring research that expands the notion of academic US literacy by valorizing and legitimizing that we are transliterate, translingual, and transcultural. However, such focus in current research does not always translate to day-to-day practices for students and for teachers. Even though scholars such as Bruce Horner, Min-Zhan Lu, Jacquelyn Jones Royster, and John Trimbur argue that a translingual approach "sees difference in language not as a barrier to overcome or as a problem to manage, but as a resource for producing meaning in writing, speaking, reading, and listening" (303), the reality of teaching undergraduates and graduates in a university setting established by and for an Anglo mainstream often erases such approaches when not addressed explicitly. In such a setting, communicative acts, instead of following the tenets of translingualism, continue to embrace largely monolingual ideologies where anything different is dismissed and devalued.

To disrupt traditional dominant ideological and pedagogical approaches to writing instruction, we understand that we need to foreground our experiences as members of a community of transnational, translingual, and transcultural academics who constantly shift language practices depending on who their audience is and what the various purposes of the literacy interactions are. Instead of marginalizing these experiences and normalizing what is marginal, we advocate for spaces that encourage the diverse and sometimes contradictory ideological approaches to language and literacy learning and teaching at US academic institutions. Like Nancy Bou Ayash, we want to "identify, question, modify, and alter" (11) the dominant approach and bring in our own complex 
and fluid ideologies and our own literacy and language experiences to make sure that our students' experiences and their literacy and language practices are not located, as Bruce Horner and Laura Tetreault remind us when they discuss translingual writing pedagogies, "outside material social history, as timeless, discrete universals against which language practices are to be measured, but in the material social realm as the always-emerging outcome of those practices" (5).

Being transliterate, and understanding the "varied patterns that transnational literacy practices take" (Guerra, "Trans-ing" 132), requires us to look closely at our own practices and how those practices can be integrated into higher education. As Latina and Austrian faculty in a US academic system, we have much practice with researching and addressing the need for a more inclusive discussion on language and literacy pedagogies (see Barrón; Barrón and Gruber; Barrón, Gruber, and Grimm; Gruber; Gruber and Barrón). As teachers and researchers, we continue to work with Street's concept of "literacy and the social practices with which it becomes associated" ("What's 'New"' 77) to make sure that discussions on the fluidity of literacy and language practices lead to changes in how writing is taught. We want to make sure that literacy is understood as the "broader cultural conception of particular ways of thinking about and doing reading and writing in cultural contexts" ("What's 'New" 79), where our diverse communicative abilities are acknowledged and valued, and where we can actively participate in nurturing and promoting the many literacies of non-dominant students and faculty. For us, this means providing mentoring support, discussing strategies for learning and applying multiple discourse conventions, and creating professional learning communities focused on approaching writing as fluid and situational and on seeing literacy as ideological and ontological. 


\section{WORKS CITED}

Alvarez, Steven. "Brokering the Immigrant Bargain: Second-Generation Immigrant Youth Negotiating Transnational Orientations to Literacy." Literacy in Composition Studies, vol. 3, no. 3, 2015, pp. 25-47, licsjournal.org/OJS/index.php/LiCS/article/view/96. Accessed 22 June 2020. Anzaldúa, Gloria. Borderlands/La Frontera: The New Mestiza. Aunt Lute, 1987.

Auerbach, Elsa. "Literacy and Ideology." Annual Review of Applied Linguistics, vol. 12, 1992, pp. 7185.

Barrón, Nancy G. "Dear Saints, Dear Stella: Letters Examining the Messy Lines of Expectations, Stereotypes, and Identity in Higher Education." College, Composition and Communication, vol. 55 , no. 1, 2003, pp. 11-37.

Barrón, Nancy G., and Sibylle Gruber. "Diversity Reconsidered: Teaching U.S. Heterogeneity in a Border State." The International Journal of Diversity in Organisations, Communities and Nations, vol. 7, no. 4, 2007, pp. 195-208.

Barrón, Nancy G., Sibylle Gruber, and Nancy Grimm, editors. Social Change in Diverse Teaching Contexts: Touchy Subjects and Routine Practices. Peter Lang, 2006.

Besnier, Niko, and Brian Street. "Aspects of Literacy." Companion Encyclopedia of Anthropology, edited by Tim Ingold, Routledge, 1994, pp. 527-62.

Bollig, Chase. “People Like Us': Theorizing First-Generation College as a Marker of Difference." Literacy in Composition Studies, vol. 7, no. 1, 2019, pp. 22-43, licsjournal.org/OJS/index.php/ LiCS/article/view/207. Accessed 29 June 2020.

Bou Ayash, Nancy. Toward Translingual Realities in Composition: (Re)working Local Language Representations and Practices. Utah State UP, 2019.

Delpit, Lisa. Other People's Children: Cultural Conflict in the Classroom. 2nd edition, The New P, 2006. Gee, James P. Social Linguistics and Literacies: Ideology in Discourses. 2nd ed., Routledge, 1996.

---. "What Is Literacy?" The Journal of Education, vol. 171, no. 1, 1989, pp. 18-25.

Gruber, Sibylle. Literacies, Experiences, and Technologies: Reflective Practices of an Alien Researcher. Hampton P, 2007.

Gruber, Sibylle, and Nancy G. Barrón. "Redirecting Failure: Controlling a Sense of Self.” Failure Pedagogies: Systems, Risks, Futures, edited by Allison D. Carr and Laura R. Micciche, Peter Lang, 2020, pp. 83-95.

Guerra, Juan C. "Emerging Representations, Situated Literacies, and the Practice of Transcultural Repositioning." Latino/a Discourses: On Language, Identity \& Literacy Education, edited by Michelle Hall Kells, Valerie Balester, and Victor Villanueva, Heinemann, 2004, pp. 7-23.

---. "Trans-ing Our Way through Matter and Meaning." Literacy in Composition Studies, vol. 3, no. 3, 2015, pp. 131-33, licsjournal.org/OJS/index.php/LiCS/article/view/101/134. Accessed 24 June 2020.

Heath, Shirley B. Ways with Words: Language, Life and Work in Communities and Classrooms. Cambridge UP, 1983.

Horner, Bruce. “Ideologies of Literacy, 'Academic Literacies', and Composition Studies.” Literacy in 
Composition Studies, vol. 1, no. 1, 2013, pp. 1-9, licsjournal.org/OJS/index.php/LiCS/article/ view/4/6. Accessed 24 June 2020.

Horner, Bruce, and Laura Tetreault, editors. Crossing Divides: Exploring Translingual Writing Pedagogies and Programs. Utah State UP, 2017.

Horner, Bruce, Min-Zhan Lu, Jacqueline Jones Royster, and John Trimbur. "Language Difference in Writing: Toward a Translingual Approach.” College English, vol. 73, no. 3, 2011, pp. 303-21.

Powell, Katrina M., and Pamela Takayoshi. "Accepting Roles Created for Us: The Ethics of Reciprocity." College Composition and Communication, no. 54, vol. 3, 2003, pp. 394-422.

Street, Brian V. "What's 'New' in New Literacy Studies? Critical Approaches to Literacy in Theory and Practice." Current Issues in Comparative Education, vol. 5, no. 2, 2003, pp. 77-91.

---. "Literacy Events and Literacy Practices: Theory and Practice in the New Literacy Studies." Multilingual Literacies: Comparative Perspectives on Research and Practice, edited by Marilyn Martin-Jones and Kathryn E. Jones. John Benjamins, 2001, pp. 17-29.

---. Literacy in Theory and Practice. Cambridge UP, 1984.

---. Social Literacies: Critical Approaches to Literacy in Development, Ethnography and Education. London, Longman, 1995. 